\title{
E-Module for Learning Volley Ball Using Character Based on Adobe Flash Cs6
}

\author{
Dian Estu Prasetyo \\ Universitas Dharmas Indonesia \\ Email: diansemutireng@gmail.com
}

Fitry Handayani

Universitas Dharmas Indonesia

Email: fitryhanda99@gmail.com

\section{A R T I C L E I N F O \\ Article history: \\ 1 Mei 2020 Received in \\ revised form \\ 11 Juni 2020 \\ Accepted 10 Juli 2020 \\ Available online 25 Agustus 2020 \\ Kata Kunci: \\ E-Modul, Bolavoli, Adobe \\ Flash CS 6}

Keywords:

character, e-modul, volley ball

\begin{abstract}
A B S T R A K
Rendahnya karakter dan pemahaman mahasiswa terhadap ketrampilan teknik dasar bolavoli. Tujuan penelitian dan pengembangan ini menghasilkan e-modul pembelajaran bola voli berbasis karakter untuk mahasiswa menggunakan Adobe CS 6 dengan kriteria valid, praktis, dan efektif. Penelitian ini adalah penelitian pengembangan (Research and Development). Penelitian ini mengunakan model ADDIE yang terdiri dari 5 tahap: analisis kebutuhan (analysis), mendesain (design), mengembangkan (develop), pelaksanaan (implement), evaluasi (evaluate). Data penelitian adalah data kuantitatif, yaitu data diambil dari hasil evaluasi yang dilakukan validator dan data praktikalitas diambil dari hasil respon dosen dan mahasiswa terhadap e-modul. Instrumen penelitian ini adalah angket validasi, angket kepraktisan, lembar efektifitas karakter mahasiswa, lembar efektifitas penilaian keterampilan bolavoli. Hasil penelitian e-modul pembelajaran bolavoli berbasis karakter untuk mahasiswa menggunakan adobe flash cs-6 telah memenuhi kriteria valid, praktis dan efektif. Dari hasil tersebut, e-modul dapat digunakan untuk mahasiswa pada perkuliahan bolavoli.
\end{abstract}

\begin{abstract}
A B S T R A C T
The low character of students plus the absence of learning resources that support learning about basic volleyball technical skills in the Covid-19 pandemic situation makes it difficult for lecturers to teach. The purpose of this research and development was to produce a character-based volleyball e-module for students using Adobe CS 6 with valid, practical, and effective criteria. This research is a development research. This research used the ADDIE model which consists of 5 stages, namely, needs analysis (analysis), design (design), develop (develop), implement (implement), evaluate (evaluate). The research data was using quantitative data that the data were taken from the results of the evaluation by the validator and the practical data was taken from the responses of lecturers and students to the e-module. The research instruments were validation questionnaires, practicality questionnaires, student character effectiveness sheets, volleyball skills assessment effectiveness sheets. The results of the e-module research on character-based volleyball learning for students using Adobe Flash CS-6 have met the criteria of being valid, practical and effective. From these results, the e-module volleyball learning based on character education for students using adobe flash CS 6 is effective for learning, especially in volleyball lectures, namely the basic technique of volleyball.
\end{abstract}

\section{Introduction}

Physical education, sports and health are compulsory subjects that are applied at all levels of education by using physicality as the intermediary. Physical education is an effort made to influence the growth and development of children towards physical or physical life which is programmed scientifically, directly and systematically and prepared by competent educational institutions (Ashfahany et al., 2017; Yusmar, 2017). Maximizing children's growth and development can surely be done by exercising regularly. Sport is a part of human daily activities that is useful to form a healthy body and spirit (Candrawati et al., 2018; Widodo, 2014). One of the sports that can be used to help children's physical development is volleyball.

The game of volleyball is a complex game, in which the game requires coordination of motion that can really be relied on to carry out all the basic technical movements of volleyball, namely under passing, over passing, under serving, top serving, smash and dam (Faozi et al., 2019; Lestari et al., 2019).

Passing is a technique of receiving the ball and swinging it back in the desired direction. Some of the basic movements of volleyball such as: Firstly, the under pass is used when receiving a service or also when receiving a smash. The second over passing technique is prioritizing the fingers of both hands, usually this technique is 
preferred when a player is about to make a pass before the last shot or smash. Third, lower serves are the first strokes that are taken from behind the finish line of the playing field over the net to the opponent's area. Fourthly, top services are a form of service with the aim of bouncing the ball towards the opposing court across the net by hitting the ball from above the head of the ball as if it is floating. The next, the smash technique is a major blow in attack to achieve victory. Lastly, blocking techniques are actions taken to form a fortress to fend off attacks from opponents (Putra et al., 2019; Rendra et al., 2018). In addition, volleyball is a team game that requires good cooperation.

However, based on observations made by researchers, there are problems with the volleyball learning process, namely about student character such as individualism, lack of discipline, lack of responsibility, disobedience to lecturer instructions and the absence of use of learning resources published by universities for students also causes the learning process especially in volleyball technique often experience an error because during the learning process sometimes students do not pay attention to the lecturer delivering the material, so that when assigning one form of movement the lecturer can repeat up to 3 times even more with a limited time. To overcome these problems, of course, an effort is needed to solve the problems.

Based on the above problems, one effort that can be done is to develop a learning resource by utilizing existing technology. Learning resources are one of the things that support learning activities. By using learning resources, it will help teachers explain the subject matter and will help students understand the subject matter being studied. One of the learning resources used in learning is teaching materials. Teaching materials have an important role in learning because using teaching materials will make it easier for educators to deliver material and help students to understand the material being studied (Andani \& Yulian, 2018; Cahyono et al., 2018; Pratiwi et al., 2017). One of the teaching materials that can be developed is e-modules, especially on volleyball material.

Modules are also called media for independent learning because they have been equipped with instructions for self-study, meaning that readers can carry out learning activities without the direct presence of the teacher, the teacher does not directly give lessons or teach something to their students face to face, but enough with modules developed (Mukaromah, 2018; Rahmadani et al., 2018).

E-Module is a form of digitalized module and is packaged more interactively which is displayed using a monitor or screen using a power source in the form of electricity or a notebook to operate it (Pratiwi et al., 2017; Suryanda et al., 2018). The components on the e-module can be adopted from the components in the print media module. Along with the era of globalization, the implementation of learning today requires technology-based learning resources. Technology-based learning resources can make students adapt to current developments in the IT (Information and Technology) field. One of the technology-based learning resources that can be used as a support for existing ones is the E-module which is packaged in the form of e-learning.

The character-based volleyball e-module developed uses Adobe Flash C6. The module is developed as an innovative and interesting learning resource to maximize the use of electronic media by students. E-modules are expected to be able to accommodate students' interests and learning styles in today's digital era because technology currently plays an important role in the advancement of education. This e-module can be applied to a multimedia technology so that it can be a learning resource that will be more interesting than the usual print media module. So that one of the applications that is part of the Adobe Flash C6 application can be used is Adobe Flash Professional S6 (Pritandhari \& Wakijo, 2020; Septryanesti \& Lazulva, 2019).

During its development, the Adobe Flash Pro program has made many improvements in each version; there are many facilities available in the CS6 version of Adobe Flash Pro to create vector-shaped 2D animations. Flash is designed with the ability to create reliable and lightweight 2-dimensional or 3-dimensional animation so that flash is widely used to build and provide animation effects on websites, interactive CDs and others. Besides that, this software can also be used to create animated logos, movies, games, and development of other website applications (Chrisyarani \& Yasa, 2018; Novrianti et al., 2018).

This research is supported by relevant previous research such as: (1) research conducted by (Eza Yayang, 2019) who get the results that web-based e-modules are declared worthy of being a learning resource that can help students learn lecture material independently, can be accessed anytime and anywhere so that they can provide students with motivation in learning and optimize student learning in an effort study lecture material. (2) research conducted by (Imansari \& Sunaryantiningsih, 2017) who got the research results that the interactive e-module learning media that was made was feasible to be used in the teaching and learning process in the classroom in the electrical workshop course. (3) research conducted by (Utami et al., 2018) who get the result that ethnomatematicsbased e-module is proven to improve problem-solving abilities.

Based on some of the relevant research, no one has developed a character-based volleyball e-module for students using Adobe Flash CS 6. The purpose of this research was to produce learning resource products in the form of character-based volleyball learning e-modules for students using Adobe. Flash CS 6. 


\section{Method}

This research was conducted in Universitas Dharmas Indonesia. The research was carried out in nature in 2020. This type of research used development research. The development model used in this study was using ADDIE that provided an opportunity to evaluate development activities at each stage. This has a positive impact on the quality of product development. The positive impact caused by the evaluation at each stage is to minimize the error rate or product shortage at the final stage.

The subjects of the e-module trial are students of the 2nd Semester of the Penjaskesrek Study Program at Universitas Dharmas Indonesia. The research data was quantitative data that the data was taken from the results of the evaluation by the validator and the practical data was taken from the responses of lecturers and students to the e-module.

The research instruments were validation questionnaires, practicality questionnaires, student character effectiveness sheets, volleyball skills assessment effectiveness sheets. The instrument to be used is validated first. An instrument is said to be valid if it is able to measure what it wants to measure well.

The data obtained were analyzed using quantitative statistical analysis techniques. This analysis is used to calculate the level of validity, practicality, and effectiveness of the e-module being developed

\section{Result and Discussion}

The result of the analysis stage (analyze) is the initial stage in this research that called as analyzing the needs, students, and materials. First, the results of the needs analysis, from the results of interviews and observations conducted; show that there is not yet any media that can support volleyball learning in volleyball lectures. There is still a lack of character inculcation and student understanding of the basic techniques of volleyball, this is evidenced by the results of interviews with some of Undhari's 2nd semester Physical Education and Physical Education students still do not understand the basic techniques of volleyball. The use of media and modules as learning resources for volleyball has not been used properly by students so that students only get material during class hours.

Based on this explanation, it is necessary to develop a media containing the basic techniques of volleyball learning that can help students understand the correct basic volleyball techniques and can attract students' attention and there is a need for the inculcation of character values that are integrated in each of these materials in order to make a difference. Volleyball developed students' skill and their character.

The second result of the student analysis is an analysis of the condition of the student or which is related to the nature of the representation. Based on the analysis carried out in the initial interview, it showed that there were still many students who were not being honest in writing poetry, students were not interested and found it difficult to write poetry and students did not have confidence in writing or reading poetry. Therefore, we need an appropriate media.

Researchers made volleyball e-modules for students due to the lack of character building and student understanding of basic volleyball techniques, this was evidenced by the results of interviews with several Undhari Physical Education and Physical Education students in semester 2 still did not understand the basic techniques of volleyball. The use of media and modules as learning resources for volleyball has not been used properly by students so that students only get material during class hours.

Based on the needs of the module as a learning resource and the inadequate use of electronic media in volleyball learning, researchers are innovating to find solutions to develop character-based volleyball learning emodules using Adobe Flash C6. The e-module was developed as an innovative and attractive learning resource to maximize the use of electronic media by students. The development of e-modules is expected to be able to accommodate the interests and learning styles of students in the current digital era because technology currently plays an important role in the advancement of education. This e-module can be applied to a multimedia technology so that it can be a learning resource that can be more interesting than the usual print media module.

\section{Discussion}

Based on the results of the validity, practicality and effectiveness test, the character-based volleyball emodule for students using adobe flash CS 6 can be applied in universities, especially for volleyball learning for students. The validation of the integrated picture book media for character education was obtained based on the data provided by the validator. The validator is the one who validates the character-based e-module consisting of 3 lecturers, namely 2 Doctors from Filkom, and 1 Doctor from FKIP UNDHARI. The validity results show that the product developed is in the valid criteria.

From the results of the instrument validation, the results are very valid. Then the instrument can be used to test the validity of the product. In the product validity test, the product is in the valid criteria. The product is said to be valid because in terms of the feasibility of the appearance of the animated content, the construct and the 
language used are correct or in accordance with the criteria contained in the instrument so that the product is suitable to be used in the learning process. This is supported by research conducted by (Chrisyarani \& Yasa, 2018) who stated that the results show that the PPK-based thematic module is valid with a total percentage of $95 \%$, so that the KDP-based thematic module is suitable for use as teaching material to help students and teachers in the learning process.

The advantage of this e-module is that it contains learning materials that are packaged in an attractive, innovative way, both in terms of appearance and content. Students prefer to learn independently using technologybased learning resources in accordance with the 4.0 industrial revolution, because in this e-module there is basic volleyball technical material which is equipped with pictures, animation, video, character values built during learning (Putra et al., 2019; Riyadi \& Yuwono, 2015). This e-module has a simple appearance with easy-tounderstand user instructions and a menu that is displayed to take students to study independently outside of lecture hours according to the volleyball course syllabus included in this e-module (Imansari \& Sunaryantiningsih, 2017).

Based on the results of the character education-based e-module practicality test conducted on lecturers and students, it appears that e-module is very practical to use. The results of the analysis of the lecturer response questionnaire that had been filled in by the lecturer showed that the response of the lecturer to e-module based on character education with a percentage with very practical criteria because it has several characteristics, namely (1) The integrated picture book media of character education can help students in overcoming student problems (2) Make it easier for lecturers to improve basic volleyball technical skills for students (3) Make it easier for students to carry out motion tasks instructed by the lecturer because they are equipped with examples of animation movements for each volleyball movement technique (4) Equipped with instructions for using e-modules that make it easier for students to carry out motion tasks (5) Can assist students in guiding the discovery of knowledge about blavoli (6) Can have an influence on student character (7) Media content is in accordance with the syllabus and learning objectives. This is supported by research conducted by (Pritandhari \& Wakijo, 2020) who obtained the result that the use of practical modules had a positive impact of $85 \%$ on the ability to understand tax material.

While the results of student responses with very practical criteria. The product is in very practical criteria because it has several characteristics, namely (1) The appearance of the e-module is attractive to students (2) The choice of colors in the e-module is very interesting (3) The steps in using e-modules are very easy to understand ( 4) The e-module is very helpful in understanding how to do basic volleyball techniques (5) The material in the emodule adds to my cognitive value about volleyball knowledge (6) I like to use picture book media (7) the emodule helps me to do The basic technique of volleyball is equipped with examples of movements using animation.

E-modules that already have valid, effective, character-based practical criteria can be used as a learning resource for students, especially in volleyball lectures in the Penjaskesrek study program, Dharmas University Indonesia. Learning resources are very important for students to have because having interesting, innovative learning resources and using technology can increase students' interest in learning independently outside of faceto-face hours during lectures (Pratiwi et al., 2017).

The character-based volleyball e-module developed uses Adobe Flash C6. The module is developed as an innovative and interesting learning resource to maximize the use of electronic media by students. E-modules are expected to be able to accommodate students' interests and learning styles in today's digital era because technology currently plays an important role in the advancement of education. This e-module can be applied to a multimedia technology so that it can be a learning resource which can be more interesting than the usual print media module, so that one of the applications that is part of the Adobe Flash C6 application which can be used is Adobe Flash Professional S6 (Pritandhari \& Wakijo, 2020; Septryanesti \& Lazulva, 2019).

This research was supported by relevant previous research such as: (1) research conducted by (Eza Yayang, 2019) who got the results that web-based e-modules are declared worthy of being a learning resource that can help students learn lecture material independently, can be accessed anytime and anywhere so that they can provide students with motivation in learning and optimize student learning in an effort study lecture material. (2) research conducted by (Imansari \& Sunaryantiningsih, 2017) who got the research results that the interactive e-module learning media that was made was feasible to be used in the teaching and learning process in the classroom in the electrical workshop course. (3) research conducted by (Utami et al., 2018) who get the result that ethnomatematicsbased e-module is proven to improve problem-solving abilities.

Based on some of the relevant research, no one has developed a character-based volleyball e-module for students using Adobe Flash CS 6. The purpose of this research is to produce learning resource products in the form of character-based volleyball learning e-modules for students using Adobe. Flash CS 6. 


\section{Conclusion}

Based on the development that has been done on the e-module, it can be concluded that the e-module volleyball learning based on character education for students using Adobe Flash CS 6 is effective to be used by students. While the results of the student character self-assessment category become student habits. The implication of e-module volleyball learning based on character education for students using Adobe Flash CS 6 is to help and facilitate lecturers in explaining the basic technical material of volleyball.

\section{References}

Andani, D. T., \& Yulian, M. (2018). Pengembangan Bahan Ajar Electronic Book Menggunakan Software Kvisoft Flipbook Pada Materi Hukum Dasar Kimia di SMA Negeri 1 Panton Reu Aceh Barat. Jurnal IPA \& Pembelajaran IPA, 2(1), 1-6. https://doi.org/10.24815/jipi.v2i1.10730

Ashfahany, F. A., Adi, S., \& Hariyanto, E. (2017). Bahan Ajar Mata Pelajaran Pendidikan Jasmani Olahraga dan Kesehatan Dalam Bentuk Multimedia Interaktif Untuk Siswa Kelas VII. Jurnal Pendidikan: Teori, Penelitian, Dan Pengembangan, 2(2), 261-267. https://doi.org/http://dx.doi.org/10.17977/jp.v2i2.8540

Cahyono, B., Tsani, D. F., \& Rahma, A. (2018). Pengembangan Buku Saku Matematika Berbasis Karakter pada Materi Trigonometri. Jurnal Phenomenon, $185-199$. https://doi.org/http://dx.doi.org/10.21580/phen.2018.8.2.2929

Candrawati, Y., Sugiyanto, S., \& Ilahi, B. R. (2018). Evaluasi Program Pembinaan Prestasi Olahraga Bola Voli Pada Smk Negeri Di Kota Bengkulu. KINESTETIK: Jurnal Ilmiah Pendidikan Jasmani, 2(1), 44-48. https://doi.org/10.33369/jk.v2i1.9186

Chrisyarani, D. D., \& Yasa, A. D. (2018). Validasi modul pembelajaran: Materi dan desain tematik berbasis PPK. Premiere Educandum, 8(2), 206-212. https://doi.org/10.25273/pe.v8i2.3207

Eza Yayang, E. (2019). Pengembangan e - modul berbasis web dengan menggunakan aplikasi moodle pada mata kuliah pengelolaan per- pustakaan. https://doi.org/https://doi.org/10.17509/e.v18i1.14113.g10011

Faozi, F., Sanusi, H., \& Listiandi, A. D. (2019). Pengaruh Model Pembelajaran Kooperatif Tipe Stad Terhadap Keterampilan Passing Bawah Dalam Permainan Bola Voli Di SMA Islam Al-Fardiyatussa'adah Citepus Palabuhanratu. Physical Activity Journal, 1(1), 51-60.

Imansari, N., \& Sunaryantiningsih, I. (2017). Pengaruh penggunaan e-modul interaktif terhadap hasil belajar mahasiswa pada materi kesehatan dan keselamatan kerja. VOLT Jurnal Ilmiah Pendidikan Teknik Elektro, 2(1), 11-16. https://doi.org/http://dx.doi.org/10.30870/volt.v2i1.1478

Lestari, D. S., Sugihartono, T., \& Sutisyana, A. (2019). Pengaruh Latihan Jump dan Depth Jump Terhadap Lompatan Block Smash Permainan Bola Voli Siswa Ekstrakurikuler SMKN 1 Kota Bengkulu. KINESTETIK: Jurnal Ilmiah Pendidikan Jasman, 3(2), $151-156$. https://doi.org/10.1017/CBO9781107415324.004

Mukaromah, S. M. (2018). Pengembangan Modul IPA Braille Berbasis Integrasi Islam dan Sains. INKLUSI: Journal of Disability Studies, 5(2), 195-216. https://doi.org/10.14421/ijds.050203

Novrianti, Hendri, N., \& Rahmi, U. (2018). E-Modul Computer Based Learning Sebagai E-Resource Digital Literacy Bagi Mahasiswa. Jurnal Educative: Journal of Education Studies, 3(1), 58-71. https://doi.org/http://dx.doi.org/10.30983/educative.v3i1.646

Pratiwi, P. H., Hidayah, N., \& Martiana, A. (2017). Pengembangan Modul Mata Kuliah Penilaian Pembelajaran Sosiologi Berorientasi Hots. Jurnal Cakrawala Pendidikan, 36(2), 201-209. https://doi.org/https://doi.org/10.21831/cp.v36i2.13123

Pritandhari, M., \& Wakijo. (2020). Analisis Penggunaan Modul Terhadap Kemampuan Pemahaman Materi Pajak. EQUILIBRIUM, 8(1), 69-74. https://doi.org/http://doi.org/10.25273/equilibrium.v8i1.5887

Putra, R., Yarmani, \& Arwin. (2019). Efektivitas Proses Belajar Mengajar Permainan Bola Voli Melalui Pendekatan Pembelajaran Games and Competition Pada Siswa Kelas V SD Negeri 14 Lebong Selatan. KINESTETIK : Jurnal Ilmiah Pendidikan Jasmani, 3(1), 99-107.

Rahmadani, Y., Tayeb, T., \& Baharuddin. (2018). Modul Matematika Berbasis Model Kooperatif Tipe Stad 
Dengan Metode Penemuan Terbimbing Pada Pokok Bahasan Teorema Phytagoras. Lentera Pendidikan : Jurnal Ilmu Tarbiyah Dan Keguruan, 21(1), 23-32. https://doi.org/10.24252/lp.2018v21n1i3

Rendra, G. R. P., Darmawiguna, I. G. M., \& Sindu, I. G. P. (2018). Pengembangan e-modul berbasis project based learning menggunakan schoology (Studi Kasus Mata Pelajaran Web Design Kelas XI Multimedia Di SMK TI Bali Global Singaraja). $\quad$ Karmapati, $\quad 7(2), \quad$ 50-58. https://doi.org/http://dx.doi.org/10.23887/karmapati.v7i2.15269

Riyadi, A. S., \& Yuwono, H. C. (2015). Pengembangan Model Permainan "Voltacer" Bola Voli Kelas Vii Smp Negeri 1 Godong Kecamatan Godong Kabupaten Grobogan Tahun 2014. Journal of Physical Education, Sport, Health and Recreation, 4(12), 2225-2230. https://doi.org/10.15294/active.v4i12.8794

Septryanesti, N., \& Lazulva. (2019). Desain Dan Uji Coba E-Modul Pembelajaran Kimia Berbasis Blog Pada Materi Hidrokarbon. JTK: Jurnal Tadris Kimiya, 2(2), $202-215$. https://doi.org/https://doi.org/10.15575/jtk.v4i2.5659

Suryanda, A., Ernawati, E., \& Maulana, A. (2018). Pengembangan Modul Multimedia Mobile Learning Dengan Android Studio 4.1 Materi Keanekaragaman Hayati Bagi Siswa Sma Kelas X. Biosfer: Jurnal Pendidikan Biologi, 9(1), 55-64. https://doi.org/10.21009/biosferjpb.9-1.9

Utami, R. E., Nugroho, A. A., Dwijayanti, I., \& Sukarno, A. (2018). Pengembangan E-Modul Berbasis Etnomatematika Untuk Meningkatkan Kemampuan Pemecahan Masalah. JNPM (Jurnal Nasional Pendidikan Matematika), 2(2), 268-283. https://doi.org/http://dx.doi.org/10.33603/jnpm.v2i2.1458

Widodo. (2014). Strategi Peningkatan Aktivitas Jasmani Siswa Sekolah Dasar di Luar Pembelajaran Pendidikan Jasmani, Olahraga, dan Kesehatan di Indonesia. Jurnal Pendidikan Dan Kebudayaan, 20(2), $281-294$. https://doi.org/10.24832/jpnk.v20i2.144

Yusmar, A. (2017). Upaya Peningkatan Teknik Permainan Bola Voli Melalui Modifikasi Permainan Siswa Kelas $\mathrm{X}$ Sma Negeri 2 Kampar. JURNAL PAJAR (Pendidikan Dan Pengajaran), 1(1), 143. https://doi.org/10.33578/pjr.v1i1.4381 